\title{
Critical teaching in classrooms of healing: Struggles and testimonios
}

\author{
Brian C. Gibbs*
}

* The University of North Carolina at Chapel Hill, School of Education, Chapel Hill, North Carolina, USA.

E-mail: bcgibbs@email.unc.edu

\section{Article Info}

Received: April 24, 2020

Revised: May 16, 2020

Accepted: May 16, 2020

\subsection{3/jcsr.02.01.6}

This is an Open Access article distributed under the terms of the CC BY-NC-ND 4.0 International license.

(https://creativecommons.org/licenses/bync-nd/4.0)

\section{How to cite}

Gibbs, B. C. (2020). Critical teaching in classrooms of healing: Struggles and testimonios. Journal of Curriculum Studies Research, 2(1), 95-111.

\begin{abstract}
Using testimonio methodology, this article describes the testimonio and struggle of two Chicanx activist social studies teachers teaching in a large urban high school serving socioeconomically poor Latinx students. Both teach critically, working to develop their students' understanding of how their ethnic and community histories contrast with larger historical narratives. Both teach the racism, misogyny, and homophobia rampant in American history by connecting it to the present. They also engage a culturally sustaining pedagogy to give students strength from their cultural inheritance. Each approached this differently, one developing an ethnic studies course, and the second developing a circulo de hombres, and embedding a youth participation action research. Each teacher tackled critical teaching and healing simultaneously from different perspectives yielding a variety of accompanying struggles.

\section{KEYWORDS}

Ethnic studies; critical pedagogy; social justice teaching; restorative justice.
\end{abstract}




\section{INTRODUCTION}

The teachers were young but had stories to tell. They had lived. The stories, the testimonios, were deep and long with histories and struggle, a past. The two teachers were, in essence, their own elders. Though inspired by others, those who had gone before, they were making the road while walking (Freire \& Horton, 1990). These teachers were attempting to build and grow classrooms of healing where the difficult truths could be exposed, analyzed and discussed. A space that allowed all participants, students and teachers, though wounded, would continue to build and grow. There were few examples of what they were trying to do, developing students who examined their own and developed a strong moral and ethical stance. The texts, teachers and ideas which guided them were from a long past, were theoretical or were thin descriptions of momentary education that were crushed or ended unexpectedly. The two teachers were heavy with the weight of creation, with resistance, and with semi-successes attempting to implement critical classrooms of healing within the constraints of an increasingly oppressive test-driven system (Au, 2008).

Using testimonio research methods and methodology (Beverly, 2003; Latina Feminist Group, 2001; Reyes \& Rodriguez, 2012) this article describes how two Chicanx activist social studies teachers teaching in a large urban high school serving underserved Latinx students "thread the needle" (Gibbs \& Papoi, 2020) to recognize the wounds students bring with them into the classroom and teach the difficult histories of racial, gendered, class, and LGBTQAI violence embedded throughout social studies curriculum (Noddings, 2012). Seeking to both teach honestly and create spaces for healing of student psyche, these teachers work to develop their students' understanding of how their ethnic and community histories contrast with larger historical narratives connecting both student histories and the American and world past to the present situation in their neighborhood. The teachers did this by relying on and wrapping their teaching in a culturally sustaining pedagogy (Paris, 1996; Paris \& Alim, 2017). Each of the teachers engaged students in a critical examination of content (Apple, 2014; Darder, 1994; Duncan-Andrade, 2007; Freire, 1970, 1998) but do so in different ways. One, Ms. Cortez ${ }^{1}$, developed an ethnic studies curriculum intimately connected to her students' neighborhood (Cuauhtin, Zavala, Sleeter, \& Au, 2019; Mason, 2019; Sleeter \& Zavala, 2020; Zavala, 2018). The second, Mr. Jacobo, developed a circulo de hombres, or a circle of men, in which male students met before school, then as a class, to discuss, analyze, and engage in acts of change outside of school; their engagement was steeped in notions of restorative justice and restorative practices (Wadwha, 2016; Winn, 2018) and embedded youth participatory action research (Y-PAR) developing students' ability to engage in community based research (Cammarota, 2014; Mira, Antero \& Morrell, 2017; Tuck \& Yang, 2013).

\footnotetext{
${ }^{1}$ All teacher names are pseudonyms.
} 


\section{Research Question}

The question guiding this paper is: How do we teach critically within classrooms of healing? Though not a new concept, the notion of a healing classroom can be traced to two general schools of thought. The first grows out of indigenous cultural beliefs and practices, restorative justice and restorative practices (Wadwha, 2016; Winn, 2018) to focus on the healing of wounds through direct conversation, discussion, and movement towards a collective remedy within a wounded space. The second school of thought emerges from psychological social work studies which examine and advocate for some focus on trauma either through teaching, pedagogy, or resilience (Carello \& Butler, 2015; Overstreet \& Chafouleas, 2016; Sondel, Baggett, \& Dunn, 2018; Thomas, Crosby, \& Vanderhaar, 2019; Venet, 2019; Zakszeski, Ventresco, \& Jaffe, 2017). Both traditions help us to understand that students are wounded or have experienced trauma by the time they reach the schoolhouse door and both traditions seek to heal or be taught with this knowledge in mind. This paper critiques this concept by arguing that too often this knowledge of wound/trauma or possible trauma is used as reason to not teach through a critical lens and to avoid content focused on race, class, gender, LGBTQAI, and violence (Gibbs, 2018, 2019a, 2019b, 2020a, 2020b, 2020c). This manuscript argues that teachers can teach through a critical lens while still providing a classroom of healing.

\section{The Teachers}

The two teachers involved in this study identify as radically left of center politically and as Chicanx critical social studies teachers. Both grew up in neighborhoods bordering the one in Southern California in which they now teach. Each of them has indicated that they identify with and "are" in many ways their students. That is, they grew up in similar low-income circumstances, in spaces surrounded by the violence of poverty, misogyny, gender, LGBTQI, racism, and police. The teachers graduated from the same teacher education program which focused on justice-oriented teaching practices in urban school contexts educating students of color. The teachers have each taught multiple levels of high school social studies and multiple subjects including World and United States History, American Government, and Economics. Each of them has also developed various electives including social-justice education, history through art, and ethnic studies, though each of them has engaged different versions of an ethnic studies pedagogy (Tintiangco-Cubales, Kohli, Sacramento, Henning, Agarwal-Rangnath, \& Sleeter, 2014). Each has taught for at least ten years and have standing and respect within both the education community and the community in which their schools stand. 


\section{GUIDING PRINCIPLES}

\section{Critical and Social Justice Teaching}

Like many educational concepts, critical and social justice teaching is broad and complicated. Critical and social justice teaching assumes that schools are raced, classed, gendered, and sexed (Apple, 2004, 2014). Further, critical and social justice teaching assumes that there are wide gaps and omissions in state-sanctified curriculum that leaves out people of color, women, and members of the LGBTQAI community. To teach critically and for social justice assumes that this is true and actively works against these omissions by introducing overlooked and undervalued knowledge to facilitate students' ability to recognize and use their own capacity to engage in advocacy for change (Gillen, 2014). Sleeter (2014) has argued there are four pillars of social justice teaching which include: (a) situating families and communities in the structural analysis offered in classrooms; (b) developing relationships with students, families and communities; (c) holding high academic expectations; and (d) teaching an inclusive curriculum. Sleeter posits that students should be engaged in these pillars through a problem posing, discussion, and inquirybased pedagogy that raises and centers student voice. A key part of critical and social justice teaching involves the development of student critical consciousness (Duncan-Andrade, 2007), what Freire (1970) calls conscientization, which then leads to praxis, or reflection, upon knowledge gained and movement towards action.

\section{Classrooms as Spaces of Healing}

While not a new concept, the idea of classrooms as spaces for healing is one made more pressing by recent recognition of the violence that racism, poverty, misogyny, and homophobia children and youth experience on a daily basis in our society. To illustrate, and there are myriad examples, the children in East Oakland, California have experienced more gun violence and death than the average soldier in Afghanistan (TED, 2011). In response to the assault of daily transgressions, teachers must create spaces for healing by embracing Freire's (1970) notion of a liberating education, an education for freedom, quite literally. To heal means to understand, to know, to take action and to have a burden lifted. Healing is steeped in the Freirian notions of praxis and concientization which are intended to raise critical consciousness (Duncan-Andrade, 2007), making students more aware of themselves and the world around them. This awareness is made possible by what is often referred to as restorative justice or more recently, restorative practices (Wadwha, 2016; Winn, 2018). Emerging from Maori indigenous beliefs, restorative justice (Zehr, 2015) seeks to restore what was damaged or who was wronged. Often done in circle, all sides are heard, and all members of the community are encouraged to participate as the community works to create a restorative solution. An event, restorative circles are different from restorative practices which are built into the everyday operations of classroom instruction as part of the ongoing pedagogy. Restorative practices seek to prevent events that would necessitate restorative circles. 
Ethnic studies operate with restorative practices in mind (Acosta \& Mir, 2012; Cuathtin, Zavala, Sleeter, \& Au, 2019; Sleeter \& Zavala, 2020; Zavala, 2018). As an insurgent pedagogy, ethnic studies seek to disrupt and interrupt traditional narratives of school that leave out the history, literature, art, and culture of students of color. Instead, ethnic studies wrap students in cultural knowledge and engage students in an ethnic studies pedagogy (Tintiangco-Cubales et al., 2014) which is discussion-based and inquiry-oriented to support students through the emergence of difficult understandings. As its name indicates, ethnic studies keeps the ethnic and racial backgrounds and experiences of students in mind as teachers seek to educate and develop the classroom as a space for healing often through indigenous methods (Sleeter \& Zavala, 2020; Zavala, 2018).

In the past few years the use of the term trauma has been used to describe what students have experienced before coming to school and in school itself. Most often referred to as traumainformed instructional practice (TIIP), it is broad term which serves as a catch-all to refer to approaches including making classrooms safe and empowering places (Carello \& Butler, 2015), restorative justice (Winn, 2018), developing trauma responsive schools (Overstreet \& Chafouleas, 2016), and focusing teacher attention on growing student resiliency and grit (Zakszeski, Bentresco, \& Jaffe, 2017). Venet (2019) argues that TIIP is simply knowing your students and providing them with support and guidance. Gorski (2018) and Nathan (2017) have critiqued the notions of grit and resiliency particularly in communities and schools with a majority of children of color. They argue that the term has racialized tones and blames students for their own lack of success rather than acknowledging the impact of systemic poverty and inequality. However, teachers can teach critically with trauma in mind and avoid the use of grit and resilience (Gibbs \& Papoi, 2020).

\section{METHODOLOGY AND METHOD}

Testimonio was used as both the method and methodology (Beverly, 2003; Latina Feminist Group, 2001; Reyes \& Rodriguez, 2012). Testimonio as a genre emerged from liberationist roots in Latin America and has been used by Chicanx activist, scholars, and authors (Reyes \& Rodriguez, 2012). Typically taking the form of first person accounts, oral history, or qualitative vignettes, testimonios are often political and "conscientizied", and are meant to speak to "right a wrong" or be an "urgent call to action" and are "situated in a liberationist pedagogy" (Reyes \& Rodriguez, 2012, p. 525). Though similar to qualitative and other forms of deep or in-depth interviewing, testimonio research differs because it is intentional in seeking to right or speak to a wrong and is purposefully political in content, tone, and use. As life story methodology (Linde, 1993; 2009) seeks to situate research within the micro-history of the participant(s) seeking to fully understand them and their experience and perspective over time, and narrative inquiry (Clandinin \& Connelly, 2000) seeks to understand participants and gather data through a series of storytelling events, testimonio (while similar to these methodologies) differentiates itself by 
being steeped in Chicanx tradition, is focused on speaking to and acting to correct injustice, and is always political in nature (Reyes \& Reyes, 2012). Unlike life history and narrative inquiry, testimonio is the methodological use of "spoken accounts of oppression" (Reyes \& Rodriguez, 2012 , p. 526) to inform others by naming issues and events, with the dual goal of inspiring corrective action and offering the speaker redemption. In this way, testimonio "is an account told in first person by a narrator who is a witness... who seeks empowerment through the use of voice" (Reyes \& Rodriguez, 2012, p. 527). The voicing of the oppression is offered as a push to create action to correct or work to remedy the injustice.

The two teachers' testimonios in this study were drawn from a larger longitudinal qualitative study that examined how self-identifying justice-oriented teachers teach for social justice in school spaces which actively attempt to constrict this teaching (Gibbs, 2019b, 2020a). Initially the interviews for these two teachers were constructed as semi-structured interviews which quickly unfolded as testimonios as the participants told passionate, richly descriptive stories of their experiences and struggles attempting to develop classroom spaces that were both critical pedagogically and healing in terms of community. Each of the teachers has been engaged in testimonio dialogue twice per year, once per academic semester, for the past four years. The testimonios were recorded and transcribed in full by the author.

Rather than analyzing by coding, the stories within the interviews were identified and surfaced and organized into narrative form. This work was done collaboratively with the participants. The resulting testimonios were transcribed and sent to the participants. Because they are working teachers with professional and familial obligations that demand much of their time, I pre-identified story themes and indicated which narratives stood together as testimonios which would be of use to the educational community through publication in academic articles, book chapters, or practitioner publications. Participants marked texts, struck some narratives, expanded or clarified others, and agreed to or negotiated the narrative structure. This was typically done through a series of discussions and conversations until a narrative order for each testimonio was agreed upon with each participant. The testimonios presented below are the result of collaborative engagement between the researcher and participants.

\section{Positionality}

I was a social studies teacher for 16 years in an urban school context. I emerged from a teacher education program that identified as social justice. During my years as a teacher, I taught through a critical and justice-oriented perspective, because I believe that it is necessary for a robust democracy and for students to wrestle with the horror and difficulties presented honestly in social studies content. As a researcher and teacher educator I work to develop critical justice- oriented teachers who teach using this perspective while simultaneously creating classrooms spaces of healing. I assume that school is not an apolitical or amoral space. I work to educate teachers who intentionally seek to create spaces in which students develop rich moral 
identities by engaging in complex moral and ethical questions and content. I did not enter into this research without a perspective. I identify as a white, cis-gendered, straight male.

\section{THE TESTIMONIOS}

\section{Ms. Cortez: "It's a miracle it came to be."}

Ms. Cortez had long dark hair with long strands of gray on the edges. During our conversation she had a deep undercut, shaved into the back of her hair and one side, causing her hair to fall on her right shoulder. She was speaking about how her Ethnic Studies course was developed.

It's a miracle it came to be. I graduated from my teacher education program, got hired at Patton High School ${ }^{2}$ and was happy. Teaching was a struggle...but I always knew it would be. Our program [teacher education] talked about that a lot, that to teach for social justice, to build a critical consciousness in your students was going to be hard, the students would struggle with it because it was new and different to them and the system, the school, the curriculum, the administration were likely going to all be opposed to it. So, I knew I was in for a fight.

She laughed after she said that, mirthfully and with a wry smile. Ms. Cortez spoke about how she at first worked at subversion. She quoted Audre Lorde (2012) about "using the master's tools" at first but later working to interrupt and disrupt these tools' utility. Initially, she worked through the established curriculum teaching world and United States History through what she would later identify as an ethnic studies pedagogy (Tintiangco-Cubales et al., 2014). Cortez formed her units around large critical questions that pushed students to analyze the content examining instances of oppressions and possibilities of resistance. She included content typically excluded from the content, particularly moments of racial violence so her students "could understand it all".

The department was dead...I mean like...without a pulse. There were two or three of us that were doing something different or struggling to...we were labeled 'radicals' right away. It was teasing at first because the few of us were younger, newer, but it gained a sharp edge over time. They saw us as not doing our jobs, not doing what we were supposed to. They wanted to follow all the guidelines from the district as if they were handed down from the divine...They didn't want to talk about anything different, unique, critical much less do it in their classrooms. When the ethnic studies class took off and schools and universities asked me to present...that was the end...I mean we couldn't...it was like there was a jealous anger that we just couldn't get over. But before that I was pink slipped.

When Ms. Cortez was pink slipped, she landed a teaching position at an art themed magnet school whose students were racially diverse and more affluent than at Patton High. The

\footnotetext{
${ }^{2}$ A pseudonym
} 
classes were tough. They resisted the critical lens and the students resisted discussion and inquiry, and ironically, Cortez indicated engaging in social studies art projects. It was a struggle that she lost with both her students and the school more generally. After two years of discord, at about the time she was considering leaving teaching, she got a call from the new principal at Patton.

He was looking to start a $9^{\text {th }}$ grade course social studies course. He wanted it focused on the local community and so did I but, I wanted it to be something else too. I told him I'd do it if it could be an ethnic studies course. I don't think he knew what that meant but he agreed. He regretted it later when he accused me of indoctrinating students, but that's how the class began. It started as a $9^{\text {th }}$ grade elective, ethnic studies connected intimately to the history, culture, and oppression of the neighborhood. It proved so popular it became a mandatory 9th grade social studies course. But looking back, it's a miracle it came to be.

"I needed to be healed." I grew up not far from here but when to a different high school. I was a good student, got A's...did the homework, passed the tests...took all the advanced placement course work and kinda bought the party line I guess. 'Education as the gateway out of the 'hood.' I never saw the racialized implications of that till years later. It would be years before I realized I had been colonized...imperialists had planted flags on my brain. It was Chicanx Studies courses in college that began to unravel me and set me free. Things began to make sense to me. How I was raised, what I experienced, how I was treated. How it wasn't my family's fault, it was more complicated, the anger, the poverty. It was so freeing and inspiring to learn I came from a long line of warriors, artists, poets, scientists, mathematicians even who were wiped out...we were... but we survived. It was the toughness that I think really got to me, that I was more, I was from a history of survivors. But I was angry for a really long time after that realization...। mean I still am but it's different now, focused. I needed to be healed.

Ms. Cortez described how her Chicanx Studies courses raised her critical consciousness, expanded her point of view and understanding, but she said, "I am not angry at them, but it did set me up for years of anger and rage that I wasn't quite sure what to do with. The teaching helped settle me to a simmer, I felt like I was doing something, doing something good, but I began to realize I was passing on my pain." She noticed that her students were becoming upset, disconsolate, and angry. "Even when we weren't talking directly about Latinx people they were connecting the pain of others to their pain, but they couldn't really articulate it I don't think. I would hug them and talk to them...but it wasn't healing them, it was deepening or creating more wounds I guess." The summer after her offer to return to Patton High School, Cortez attended a Restorative Justice workshop.

It was just revelatory...it just opened my eyes to what could be. My first circle just snapped me into focus. I realized that restorative practices were going to be a cornerstone of the 
ninth grade ethnic studies class. The conversations we had during this training were just so healing. I began to realize that teaching with and through restorative practices could be a way to really look and complicated content but create opportunities to process, think through and talk about how it impacts and affects us as individuals. It's weird though and hard to sit in circle, it's uncomfortable in the beginning, awkward and I knew it would be for my students too.

"And so, we began." The course was initially designed to be a cultural geography course focused on the neighborhood in which the students grew up, as directed by the principal. Cortez and a few co-collaborators worked on the syllabus but soon began to infuse it with their own perspectives. They all had interest and experience in ethnic studies, critical race and gender studies, and these all began to find its way into the course. As the essential questions and units of instruction were developed, the course began to shift dramatically from a cultural geography class into a full-blown ethnic studies course. "How could my students understand the colonialism and imperialism at play in the shape of the neighborhood, the endemic poverty, without a broader understanding that ethnic studies provides?" Cortez was greatly impacted by the restorative justice training she had participated in and worked to embed this within the class through the theory of transformative resistance created by Solorzano and Delgado-Bernal (2001). They identify many forms of self-defeating resistance but offer transformative resistance as a way to resist and fight back against forms of oppression students would be studying and identifying through the curriculum. Transformative resistance offered students a tangible way to verbalize and understand systems of oppression alongside a way to engage in change. As Cortez explained:

It gave students traction, a path, a way to combine knowledge, understanding and resistance. In a course focused on student communities, I wanted to intentionally create a space where students could actively engage in activism and organizing in their communities. And this I think gives students a chance to heal. I knew that to fully engage in restorative practices, it had to not just be about class, but had to be connected to the outside. I can't just be about making kids feel good inside school, when the outside world is horrid. If the outside world is better, the inside school will be better, they're connected. A healed classroom cannot exist without work to heal the world.

Ms. Cortez and a small team of teachers connected with student-based activist groups in the community and within the larger city. Over the course of the school year these groups visited her class both as guest teachers sharing information, stories, and content and as links to the wider community and city. They provided ways to engage in the knowledge and healing work they learned of and experienced within their classroom setting. Activists, scholars, artists of all kinds eventually were invited into the classroom and in turn invited the students out into the community. 
There is healing in many things I've come to believe. An interdisciplinary knowledge, not just the history, but the art, music, food, hope and courage of their (students') past, has healing. Action, forward motion has healing. So many of my students were like me, they couldn't wait to get out of the ghetto. Their neighborhood, the space that made them they had seen as dirty, scary, horrid, unsafe. There was sadness and embarrassment that their family lived here that they had to live here and they could not wait to escape. I want them to heal this wound and see their community with a different lens, one of understanding and one of possibility. The mantra for the course as I taught it over the years was to help students see their community as a site of resistance, trauma, transformation, and a place of infinite possibility. The course wrestles with identity, community, mapping, colonization, racism, colorism, resistance, resilience, liberation, re-imagining, and decolonization amongst other things. And so we began. We just did it and grew and kept growing.

\section{Mr. Jacobo: "I was always looking for me."}

Mr. Jacobo's defining feature was his smile. Wide and white teeth that just took over his entire face. His hair was closely cropped and he moved with a quickness that denotes the ebullience he carries for the work that he does. He was describing where the idea for a circulo de hombres (circle of men) emerged:

I guess the reality is that my mother was my first male role model. It's funny to say out loud but it's true. And I don't think it's unusual at all for young men in my neighborhood to say that. My dad was gone early, he's like a wisp of smoke to me really, there but not really, and when I reach for him, just gone. I had an older brother but he kind of went the way of my dad, not gone, but left as soon as he could. He was older than me by a lot and just I think didn't feel connected to me. So, it was my mom that taught me to be a man. I don't mean in the stereotypical way. She showed me how to love, and be open, and share misery and cry and also to be tough, to work hard and put your shoulder to the wheel, I guess. She was gone a lot, worked a number of jobs over the years, but she was always with me ya' know? What's that Lincoln quote, "the better angels of our nature" yeah, she was always with me wherever I went. I could hear her: 'Work hard, mijo (my son).' 'Study hard, mijo.' 'Do your best, mijo.' 'Be a good man, mijo.' There was just a steady hope, a steady belief that I would do well I would become and continue to be someone she would be proud of. She didn't yell at me ever...well not very much...it wasn't that I didn't think she couldn't, she just generally didn't. Though she gave me this incredible foundation I think I spent my whole life looking for someone to emulate, a male mentor to encourage me, speak to me, call me on stuff, push me, pick me up.

When Mr. Jacobo started teaching, he noticed a certain student set that would be in his class before school, hang out after school, and haunt his room during lunch. It seemed to always 
be the male students on the margins. On the margins because they just didn't quite fit in because they cared too much about school, didn't care at all about school, were into anime or manga. They were, as Mr. Jacobo said with air quotes, "the nerds and the thugs" because they were seen that way by the larger school community, but he didn't, he saw them as himself:

I was so both parts of that growing up, I was into comic books, video games, quote unquote nerd stuff but I was also surrounded by men who dropped out, struggled with addiction, engaged in violence. I realized as I started teaching, I had always been looking for me, or someone like me. I decided to be that for them [his students].

"Why can't we do this more often?" Mr. Jacobo taught mostly world and United States History through a critical lens (Apple, 2014; Darder, 1994; Duncan-Andrade, 2007; Freire, 1970; Parkhouse, 2017). He also indicated that ethnic studies courses, particularly courses in Chicanx Studies, deeply influenced his Freirian $(1970 ; 1998)$ approach to teaching through problem posing, discussion, and inquiry, infusing his history teaching with literature, poetry, and art. He was, in essence, engaging in an ethnic studies pedagogy (Tintiangco-Cubales et al., 2014) surfacing overlooked ethnic groups, racial violence, and resistance not included in the official curriculum (Apple, 2014).

Over time, Restorative Justice [RJ] just made more sense to include. My pedagogy was dialogic and critical by nature, but it was missing the direct reflective nature of RJ and while I had been working on building community in my classes, it never seemed cemented. The boys who always hovered around my classes before and after school and during lunch never seemed to be integrated into class. RJ helped this immensely. The ceremony of the circle, the focus on remedying a wrong or at least working towards it was wonderful. It built community without ever saying, 'Hey, we're building community here.' The first time I ran a circle in class happened because two students-a male student, one of the boys who hangs out in my classroom, and a female student-exchanged words that quickly became gender specific and racialized. They're friends but their banter went sideways and resulted in both them, even they're both Latinx getting into racial, poverty based and gendered stereotypes and yelling at each other. It happened before class and I didn't see it, but it was tense all the way through class. Afterwards, Jazmin, the female student asked that something be done. I held a 'harm circle' the next day.

The mood was different that next day, no music playing, he did not greet students at the door as he usually did, he even had the door locked. He did not let students into the room until after the tardy bell had rung. When students walked in the room had been moved into a circle. Students were instructed to take a seat.

I greeted students with an Arabic greeting, 'Assalaam Alaykum,' and the students responded with the same greeting. I used different ethnic greetings to open class. I told students that students were harmed yesterday. I introduced students to the idea of an RJ circle that it was similar to a Socratic Seminar (Roberts \& Billings, 2011) in that we sit in a 
circle and discuss a text, but this time the text was the event that happened and what we needs to be done to heal. I introduced students to a talking piece telling them that only the person holding the piece could speak. I told students to listen with their hearts and speak from their hearts with respect. Be sure that what you say does no harm. The students were all nervous and so was I. While I had conducted many discussions, I had never facilitated something so personal, it felt truly risky. 'We have two questions to consider today. First, what harm has been done? Second, once harm has been committed how do we move forward and heal?' The discussion took place in two rounds, one for the first question and one for the second. The talking piece made it from student to student, some sharing what they witnessed others choosing not to speak. It then came to one of the students involved. She stood and spoke her truth, admitted what she had done and explained how she had also been harmed. She cried quietly then sat down. I asked all students to show appreciation for her courage. They did by doing the sign language sign for clapping, something I'd shown them earlier. The young man spoke a few minutes later making eye contact the entire time. He admitted what he had done and admitted he had been harmed. He didn't cry exactly but seemed to be shaking. We spoke for a while and spoke about what could have been done differently and what could be done now. The students spoke really generally but that was ok, it was our first time. The most important part was what happened next. A student, a young man who had been in my class before and after school, except when he was ditching class, which was pretty often said, 'Why can't we do this more often?' And that was it, RJ for life.

"I'm so glad we built this." Several conversations later, with the young man who spoke at the end of the RJ circle and several other students in the BAL squad [Before, After, and Lunch], Mr. Jacobo began what he termed a circulo de hombres, or circle of men. They began by meeting before school for just 20 minutes, a RJ circle once a week. The students soon began to ask for more, so they began meeting after school twice a week.

I know it sounds like the white dudes in the woods beating on drums and hugging each other, but that's what it was, a space for kids, young men, to feel safe, comfortable, and really talk. I sold it, when I spoke to young men about it by describing the circles the Lakota warriors would sit in before and after battle. Before battle they would share their fears and their worries as they headed into battle. After they would share the weight of their sins, the violence they witnessed and the violence they engaged in. This notion of it being a warrior space seemed to entice them, 'nerds' and 'thugs' alike. It was such an interesting mix of young men who began to mesh.

By the end of the first semester, Mr. Jacobo's circulo de hombres had 25 regular attendees twice a week for over an hour and about five others who would sporadically attend. "The funny part was that students would skip school all day then come to circle." This is when Mr. Jacobo began to lobby the principal to get the group designated as a course. It was a struggle, a 
semester long fight of logistics, course names, and scheduling that worked for the youth, but eventually it was granted. It was during the second semester that Mr. Jacobo received a challenge.

We were in circle one afternoon talking about a problem that we saw at school when a young man said, 'We talk a lot in here...are we ever going to learn how to do anything about it?' I remember I was drinking water and I almost spit it out I was laughing so hard. I was laughing not at him but the obviousness of his comment. I had used Y-PAR [Youth Participatory Action Research] in the past and this space was the perfect place for it, but I hadn't made that connection till then. The next meeting, I began to grow researchers.

As part of the circulo de hombres Mr. Jacobo began to walk his students through the $\mathrm{Y}$ PAR process. He began by leading them through a series of discussions about what problems they saw in their school and neighborhood, then taught them how to make problem statements into research questions. They worked on this for a time then focused on what types of research qualitative, quantitative or mixed would lead to the best result, then how to analyze their data and write research reports and make presentations. Students were also asked to develop possible solutions to the problem based on their research.

It was a struggle. The students loved the problem identifying, they were good at it and got really strong at developing questions, but the design of study was hard for them to wrap their head around not to mention the analysis portion, but we grew into it. We decided for the first round to focus on school-based issues and problems. The problems raised were everything from students ditching class, suggested by the two most notorious ditchers I have ever had to trash on campus, to students get labeled as failures, to student drug testing, to gender issues in sports (women's sports were given the lesser of fields to practice and play on). The students did well. They designed surveys, conducted interviews, chased down outside experts for facts and evidence and wrote up reports. The students complained, 'But Mr. Jacobo, this wasn't supposed to be a real class.' And, 'That's due today?' But they laughed and smiled while they complained. We held an after-school event where administration came as well as parents and community supporters to witness the presentations. I think it was when admin saw what the young men had done that, they decided to allow it to become a class. Because it did the next year. The students presented their data, the research process, and their recommendations. They spoke directly to administration, several students a bit aggressively but it was received well by school leadership. They were impressed with the young men and told them so. We ended the presentations with a circle including the young men and all those in attendance. It was a high. The students saw that they were heard and heard that they were seen. They felt it all. A young man ended the ceremony with a statement I think about all the time, 'I'm glad we built this'. What was interesting to me was he wasn't just talking about me and the young men he was talking about all those in attendance. The this he was talking about was 
the continuation, the continued conversation, the continued work. The students looked at hard things and grew from it. They fought back against it and I think it that, in the struggle to be seen, heard, recognized, identified as something more, they and I, I know for sure, were healed.

\section{DISCUSSION AND CONCLUSION}

Though taking different paths, Ms. Cortez and Mr. Jacobo engaged their students similarly, namely that they engaged in ethical and moral dilemmas through a critical examination of content (Apple, 2004, 2014; Freire, 1970). As important, both teachers taught students the importance of healing, of working through the pain and the discomfort that an honest look at content creates. Having been wounded themselves and in search of healing, both Ms. Cortez and Mr. Jacobo found ways to raise the critical consciousness, moral and ethical awareness of students, and offered their classrooms as spaces of healing and growth. One, both teachers agreed, could not happen without the other. There would be no healing without acquiring new knowledge, and both provided opportunities for just that. Ms. Cortez developed an ethnic studies program that explored the history of the neighborhood, both wrapping students in the knowledge and understanding of community wealth and community difficulty. Mr. Jacobo, recognizing a need amongst the young men of his classes, developed the circulo de hombres to begin to find a place for them, a space to heal and eventually through the community's push, to become activist through the use of youth participatory action research where students found strength and a voice.

Neither teacher avoided difficult topics; instead, they fostered a critical sensibility among their students by engaging directly in social justice issues related to race, gender, poverty, sexuality, and resistance. Both recognized the need to not leave students there, in the space of knowing and understanding the damage that violence had caused, but instead sought to help their students find a place for this knowledge to settle through restorative measures and action. Both teachers understood that students need to be made cognizant of their own power and their own ability to save themselves and fight for their community. Both Ms. Cortez and Mr. Jacobo took different paths that led their students to similar spaces of healing and action.

Engaging students in moral and ethical growth is not easy. More than a teacher disposition or pedagogical approach, these testimonios reveal that a broader understanding is necessary. A raised consciousness can inflict or cause new awareness of wounds. By engaging an ethnic studies approach (Tintiangco-Cubales et al., 2014) with embedded restorative practices (Acosta \& Mir, 2012; Cuathtin et al., 2019; Sleeter \& Zavala, 2020; Zavala, 2018) teachers can both teach for social justice and offer a critical examination of content as well as offer students the possibility of healing. To develop robust ethics and morality, students must face, examine and understand the darkness of our history and be inspired to engage in acts of change on the personal, local, national and global levels. There is weight and heaviness to this work and to the 
knowledge that comes with it. For ethical and moral growth students need to learn how to simultaneously guard and give voice to their spirits. The testimonios of Ms. Cortez and Mr. Jacobo presented above, provide insight on how this demanding work can, and must, be undertaken.

\section{REFERENCES}

Acosta, C., \& Mir, Y. (2012). Empowering young people to be critical thinkers: The MexicanAmerican studies program in Tucson. Voices in Urban Education, 34, 15-26.

Apple, M. (2004). Ideology and curriculum, (3rd ed). New York, NY: Routledge-Falmer.

Apple, M. (2014). Official knowledge: Democratic education in a conservative age, (3 $3^{\text {rd }}$ ed). New York, NY: Routledge.

Beverly, J. (2003). Testimonio, subalternity, and narrative authority. In N. Denzin \& Y. Lincoln's (Eds.), Strategies for Qualitative Inquiry 2nd Edition. Thousand Oakes, CA: Sage Publications.

Carello, J. \& Butler, L. (2015). Practicing what we teach: Trauma informed educational practice. Journal of Teaching in Social Work, 35(3), 262-278.

Cammarota, J. (2014). The social justice education project: Youth participation action research in schools. In J. Cammarota \& A. Romero (Eds.), Raza studies: The public option for educational revolution. Tucson, AZ: University of Arizona Press.

Darder, A. (1991). Culture and power in the classroom: A critical foundation for bicultural education. Westport: CT: Bergin \& Garvey.

Duncan-Andrade, J. (2007). Gangstas, wankstas, and ridas: Defining, developing, and supporting effective teachers in urban schools. International Journal of Qualitative Studies in Education, 20(6), 617-638.

Duncan-Andrade, J., \& Morrell, E. (2008). The art of critical pedagogy: Possibilities for moving from theory to practice in urban schools. New York, NY: Peter Lang Publishing, Inc.

Freire, P. (1970). Pedagogy of the oppressed. New York, NY: Continuum Publishing.

Freire, P. \& Horton, M. (1990). We make the road by walking. Philadelphia, PA: Temple University Press.

Gibbs, B. C. (2018). Las Traviesas: Critical feminist educators in their struggle for critical teaching. In L. Jewett, F. Calderon-Berumen, \& M. Espinosa-Dulanto (Eds.), Critical intersections in contemporary curriculum \& pedagogy. Charlotte, NC: Information Age Publishing.

Gibbs, B. C. (2019a). Violence, horror, and the visual Image: How teachers speak about the difference between the use of photographs of war and photographs of lynching. In S. L. Raye, S. Masta, S. T. Cook, \& J. Burdick (Eds.), Ideating pedagogy in troubled times: Approaches to identity, theory, teaching, and research. Charlotte, NC: Information Age Publishing. 
Gibbs, B. C. (2019b). "I guess I realized how tired I had become": In defense of social justice teaching. Critical Education, 10(10). DOI: 10.14288/ce.v10i10.186419

Gibbs, B. C. (2019c). Patriotism, pressure, and place: Civic agency in base country. Peabody Journal of Education Special Themed Edition: Civic Education in the U.S., 94(1), 97-113. DOI:10./1080/0161956X.2019.1553584

Gibbs, B. C. (2020a). Word Capture, straight refusal, teaching well and other forms of resistance: The development of critical teacher agency. Teacher Education Quarterly, 47(1), 97+.

Gibbs, B. C. (2020b). The foot and the flag: Patriotism, place, and the teaching of war in a military town. Democracy and Education, 28(1), 1-14.

Gibbs, B. \& Papoi, K. (2020). Threading the needle: On balancing trauma and critical teaching. Possibilities and problems in trauma-based and social emotional learning programs.

Occasional Paper Series, 2020(43), 101-112. Retrieved from

https://educate.bankstreet.edu/occasional-paper-series/vol2020/iss43/13.

Gorski, P. (2018). Reaching and teaching students in poverty: Strategies for erasing the opportunity gap. New York, NY: Teachers College Press.

Latina Feminist Group (2001). Telling to live: Latina feminist testimonios. Duke University Press. Linde, C. (1993). Life stories: The creation of coherence. Oxford, UK: Oxford University Press.

Linde, C. (2009). Working the past: Narrative and institutional memory. Oxford, UK: Oxford University Press.

Lorde, A. (2012). Sister outsider. New York, NY: Crossing Press.

Mira, N., Garcia, A. \& Morrell, E. (2017). Doing youth participatory action research: Transforming inquiry with researchers, educators, and students. New York: Routledge.

Nathan, L. (2017). When grit isn't enough: A high school principal examines how poverty and inequality thwart the college-for-all promise. Boston, MA: Beacon Press.

Noddings, N. (2012). Peace education: How we come to love and hate war. Cambridge, UK: Cambridge University Press.

Overstreet, S. \& Chafouleas, S. (2016). Trauma-informed schools: Introduction to the special issue. In School Mental Health 8:1-6.

Paris, D. (1996). Culturally sustaining pedagogy: A needed change in stance, terminology and practice. Educational Researcher, Vol. 41, No. 3, pp. 93-97.

Paris, D. \& Alim, (2017). Culturally sustaining pedagogies: Teaching and learning for justice in a changing world. New York: Teachers College Press.

Reyes, K. \& Rodriguez, J. (2012). Testimonio: Origins, terms, and resources. Equity and Excellence in Education, 45(3), 525-538.

Roberts, T. \& Billings, L. (2011). Teaching critical thinking: Using seminars for 21st century literacy. New York: Routledge.

Sleeter, C. (2014). Deepening social justice teaching. In Journal of Language and Literacy Education February, 2014. Retrieved from http://jolle.coe.uga.edu/ 
Solorzano, D. \& Delgado-Bernal, D. (2001). Examining transformational resistance through a critical race and latcrit framework: Chicana and chicano students in an urban context. Urban Education, 36(3), 308-342.

Sondel, B., Baggett, H., \& Dunn, A. (2018). "For millions of people this is real trauma": A pedagogy of political trauma in the wake of the 2016 U.S. presidential election. Teaching and Teacher Education, 70, 175-185.

TED. (2011, September 27). Growing roses in concrete Jeff Duncan-Andrade [Video]. YouTube. Retrieved from https://www.youtube.com/watch?v=2CwS60ykM8s

The Room 241 Team. (2018, September 4). Trauma-informed strategies to use in your classroom [Blog post]. Retrieved from https://education.cu-portland.edu/blog/classroomresources/trauma-informed-strategies/

Thomas, M. S., Crosby, S., \& Vanderhaar, J. (2019). Trauma-informed practices in schools across two decades: An interdisciplinary review of research. Review of Research in Education, 43(1), 422-452.

Tintiangco-Cubales, A. Kohli, R., Sacramento, J., Henning, N., Agarwal-Rangnath, R. \& Sleeter, K. (2014). Toward an ethnic studies pedagogy: Implications for K-12 schools from research. In Urban Review, 47, 104-125. DOI 10.1007/s11256-014-0280-7.

Tuck, E. \& Yang, K. W. (2013). Thinking with youth about theories of change in E. Tuck \& K.W. Yang (Eds.) Youth Resistance Research and Strategies for Change. New York: Routledge.

Venet, A. S. (2019). Role-clarity and boundaries for trauma-informed teachers, Educational Considerations, 44(2), 1-9.

Wadwha, A. (2016). Restorative justice in urban schools: Disrupting the school-to-prison pipeline. New York: Routledge.

Winn, M. (2018). Justice on both sides: Transforming education through restorative justice. Harvard Education Press: Cambridge, MA.

Zakszeski, B., Ventresco, N. \& Jaffe, A. (2017). Promoting resilience through trauma-focused practices: A critical review of school-based implementation. School Mental Health, 9, 310-321.

Zehr, H. (2015). The little book of restorative justice. New York: Skyhorse Publishing. 